\title{
Cissampelos sympodialis Eichl. (Menispermaceae) inhibits anaphylactic shock reaction in murine allergic model
}

\author{
C.R. Bezerra-Santos ${ }^{1}$, L.M.T. Peçanha ${ }^{2}$, M.R. Piuvezam ${ }^{1 *}$ \\ ${ }^{1}$ Laboratório de Tecnologia Farmacêutica, Departamento de Fisiologia e Patologia, Universidade Federal da \\ Paraiba, Caixa Postal 5009, 58051-970, João Pessoa, PB, Brazil, \\ ${ }^{2}$ Departamento de Imunologia, Instituto de Microbiologia Prof. Paulo de Góes, Universidade Federal do Rio de \\ Janeiro, 21944-970, Rio de Janeiro, RJ, Brazil
}

\begin{abstract}
The murine model of OVA-induced immediate allergic reaction was used to evaluate the effectiveness of intraperitoneal sub-acute treatment with the leaf hydroalcoholic extract of Cissampelos sympodialis (AFL) in the anaphylactic shock reaction, IgE production and the background proliferative response. BALB/c mice treated with AFL ranging from 200 to 400 $\mathrm{mg} / \mathrm{kg}$ /day for 5 days before and during OVA-sensitization strongly reduced the animal death and promoted reduction in total and OVA-specific serum IgE level. Spleen cells from AFL-treated sensitized animals showed a decreased proliferative background response when compared with non-sensitized animals. These results demonstrated that sub-acute intraperitoneal treatment with Cissampelos sympodialis extract has an anti-allergic effect.
\end{abstract}

Keywords: Cissampelos sympodialis, BALB/c mice, sub-acute treatment, anaphylactic shock reaction, Immunoglobulin E.

\section{INTRODUCTION}

Anaphylactic shock reaction is a serious and potentially lethal systemic reaction caused by immediate allergic response (Moneret-Vautrin et al., 2005). It is well described that food, drugs and insect bits might evoke fatal anaphylaxis in sensitized subjects, and the number of death related to allergic response has increased in the last years (Scott; Donald, 2004).

New drug researches to allergic responses have indicated that medicinal plants consist on important tools to treat immediate allergic reactions (Dai et al., 2004). In accordance with this perspective, we studied a potential effect of a native Brazilian plant named Cissampelos sympodialis in immediate allergic response.

The genus Cissampelos is known by the presence of alkaloids (Barbosa-Filho et al., 1997) and some of these molecules have been isolated from $C$. sympodialis as milonine, laurifoline, roraimine, warifteine and methylwarifteine which has spasmolytic action (Cortes et al., 1995; Freitas et al., 1996).

In vitro immunological studies showed that the leaf hydroalcoholic extract of Cissampelos sympodialis (AFL) increased the production of interleukin-10 (IL10) and inhibited $T$ cell proliferative response in mouse spleen cells stimulated with Concanavalin-A (Piuvezam et al., 1999). AFL also induced an IL-10-dependent inhibition of Trypanosoma cruzi killing by macrophages and modulated B cell response (Alexandre-Moreira et al., 2003a,b). Studies in vivo demonstrated that intraperitoneal injection of AFL has an anti-inflammatory activity in the carrageenan or capsaicin mouse ear edema (Batista-Lima et al., 2001).

In addition, Bezerra-Santos (2004) showed that oral treatment with AFL reduced not only total and OVA-specific IgE level but also induced INF- $\gamma$ production in sensitized BALB/c mice. Taking together both in vitro and in vivo studies described above, it can be suggested that Cissampelos sympodialis has an important immunopharmacological activity.

Some types of immediate allergic reactions are now considered to be a disorder associated with increased of IgE levels (Mayr; Zuberi; Liu, 2003). IgE responses might be lethal due to mediators delivering such as histamine from mast cell sensitized with IgE and consequent anaphylactic shock reaction (Reviewed by Finkelman et al., 2005; Strait et al., 2002).

Compound 48/80 causes peritoneal mast cell degranulation and respective mediator releases (Kim et al., 2000). Indeed, this molecule seems activate mast cell directly without specific receptor differently IgE responses (Ferry et al, 2002). Studies using compound $48 / 80$ have allowed understanding some plant mechanisms in order to prevent allergic diseases (Dai et al., 2004; Phil-Dong et al., 2004).

To amplify our knowledge on the suitability to use the Cissampelos sympodialis for the treatment of allergic diseases we evaluated in this study the effect of the intraperitoneal treatment with AFL in ovalbumin-sensitized BALB/c mice. The immunological aspects investigated here were the anaphylactic shock reaction induced by ovalbumin or compound $48 / 80$, 
Table 1. Effect of AFL in anaphylactic shock reaction

\begin{tabular}{lccccc}
\hline & & & & Compound & \\
Treatment & Dose $(\mathrm{mg} / \mathrm{kg})$ & Ovalbumin & Mortality $\%$ & $48 / 80$ & Mortality $\%$ \\
\hline Saline & - & + & 100 & + & 100 \\
AFL & 200 & + & $50 *$ & + & 100 \\
& 400 & + & $30 *$ & + & 100
\end{tabular}

Groups of mice $(n=10)$ received AFL sub-acute treatment before and during OVA sensitization protocol. Three weeks after the first OVA injection, the animals received OVA challenged by i.v. route. In a separated experiment, mice were treated with AFL 1 $\mathrm{h}$ before compound 48/80 injection. The mortality was monitored $1 \mathrm{~h}$ after OVA or compound 48/80 challenges. Negative control group received only saline during experimental protocols and did not present any death response. * p $<0.001$ compared with control group (OVA) and analyzed by the Fisher's test.

immunoglobulin E production and cell proliferative response.

\section{MATERIAL AND METHODS}

\section{Plant material and extract preparation}

Leaves from Cissampelos sympodialis were obtained from the Botanical Garden of the Laboratório de Tecnologia Farmacêutica/ Universidade Federal da Paraíba (voucher specimen Agra 1456). The leaves were dried at $50{ }^{\circ} \mathrm{C}$ in an oven and pulverized. The powder was extracted with $70 \%$ ethanol in water at $70{ }^{\circ} \mathrm{C}$ for 5 days. The dried extract, herein named AFL, was dissolved in water, filtered and known volumes were dried to determine the final concentration of the water-soluble components. All doses are expressed in terms of the concentration of the soluble components $(\mathrm{mg} / \mathrm{kg}$ of body weight). The yield was $22 \%$ on average, based on solid residues present (Thomas et al., 1997).

\section{Animals}

BALB/c mice (25-30 g) and Wistar rats (250$300 \mathrm{~g}$ ) were used throughout the study. The animals were supplied by the Animal Facility from the Laboratório de Tecnologia Farmacêutica (Universidade Federal da Paraíba). Groups of 10 animals were used in each test. The experimental protocols were approved by the Institutional Review Committee for the use of animal subject (CEPA $\mathrm{N}^{\mathrm{o}}$ 0602/05) of the Federal University of Paraiba, Brazil. All experiments were carried out with strict adherence to ethical guidelines (Sherwin et al., 2003).

\section{AFL sub-acute treatment and OVA-sensitization}

Mice ( $\mathrm{n}=10)$ were treated with AFL ( 200 or 400 $\mathrm{mg} / \mathrm{kg}$ ) dissolved in saline for 5 days before and during the sensitization protocol. On day 0 and $14^{\text {th }}$ the mice were actively immunized with OVA (grade II Sigma Chemical, St. Louis, MO) by injection (i.p) of $10 \mu \mathrm{g}$ OVA adsorbed to $2.25 \mathrm{mg}$ of alum adjuvant. The control group (OVA) received only saline during the OVA immunization (Oshiba et al., 1996). Three weeks after the first OVA injection, animals were exposed to aerosol of $1 \%(\mathrm{w} / \mathrm{v})$ OVA in saline for $30 \mathrm{~min}$ (Randolph et al., 1999).

\section{Anaphylactic shock reaction}

In a separated experiment, twenty-three days after initiation of OVA sensitization, AFL-treated sensitized mice were injected intravenously (i.v.) with $200 \mu \mathrm{l} 0.5 \%$ Evans Blue solution containing $500 \mu \mathrm{g}$ OVA (Grunewald et al., 1998). Non sensitized mice were injected with $8 \mathrm{mg} / \mathrm{kg}$ of compound 48/80 (Sigma) (Kim et al., 2000). Mortality was monitored for $1 \mathrm{~h}$ after induction of anaphylactic reaction.

\section{Determination of OVA-specific antibody by the PCA test}

IgE antibody titers were determined using the passive cutaneous anaphylaxis (PCA) reaction. Serum dilutions were inoculated intradermally on the shave backs of Wistar rats. After $24 \mathrm{~h}$ the rats received intravenous injection of OVA $(2.0 \mathrm{mg} / \mathrm{rat})$ in $1 \%$ Evans Blue solution. Thirty min later the rats were euthanized and OVA-specific IgE titers were measured. The highest serum dilution giving a 5-mm diameter flare or bluing reaction was taken as the PCA titer (Holt et al., 1981).

\section{Measurement of OVA-specific and total IgE by ELISA}

Total or OVA-specific IgE from sera were measured using sandwich ELISA (Snaper; Paul, 1987). Appropriate standards, monoclonal antibodies and alkaline phosphatase-streptavidin (Pharmigen, San Diego, CA) were used as detection reagents. The calibration curve was obtained using purified IgE monoclonal antibody (Pharmigen, San Diego, CA).

\section{Cell preparation and proliferation assay}


Spleen cell suspensions were prepared and depleted of red blood cells by incubation in Boyle's solution (0.17 M Tris, $0.16 \mathrm{M}$ ammonium chloride, BDH, UK). The cells were washed twice in RPMI medium (Gibco, Pisley, UK) by centrifugation at 200x g for $10 \mathrm{~min}$. The obtained pellet was resuspended in complete RPMI medium ( $10 \%$ fetal bovine serum). Viable cell number was determined by Trypan Blue exclusion. Triplicate cultures were performed in 96-well flat-bottomed tissue culture plates (Costar, Cambridge, MA, USA) in a final volume of $200 \mu \mathrm{l}$ per well containing $4-5 \times 10^{5}$ cells. Cultures were then incubated for 3 days at $37^{\circ} \mathrm{C}, 5 \%$ $\mathrm{CO}_{2}$. Proliferation assay was performed as described by Mosmann (1983).

\section{Statistical analyses}

Data were statistically analyzed by the Student's t-test using a computer program GraphPad Prism version 3.02. Data were expressed as a mean \pm SEM. Results with $p<0.05$ were considered statistically significant.

\section{RESULTS}

\section{Effect of AFL on anaphylactic shock reaction}

Sub-acute AFL-treatment inhibited the animal rate mortality by OVA challenge at $50 \%(200 \mathrm{mg} / \mathrm{kg})$ and $30 \%(400 \mathrm{mg} / \mathrm{kg})$. However AFL-treatment did not inhibit the anaphylactic shock reaction induced by compound 48/80 injection (Table 1).

Effect of AFL on OVA-specific-IgE and total antibody production
We next investigated the ability of AFL to modify antigen-induced serum IgE production. Table 2 shows the AFL-inhibitory effect on antigen-induced IgE production. OVA sensitization induced an OVA-specific-IgE titer of 1:1.373 (100\%), whereas intraperitoneal administration of AFL at 200 or $400 \mathrm{mg} / \mathrm{kg}$ during the OVA sensitization period reduced the IgE titers by 1:588 (47\%) and 1:432 (31\%), respectively (Table 2). Similar but less striking results were obtained using the PCA assay (Table 2). We also observed a significant decrease in total antibody IgE levels in the sera of AFL-treated mice.

\section{Effect of AFL on background proliferative response}

Background of the cell proliferative response was inhibited, in a dose dependent manner, in AFL-treated mice at doses of AFL $200 \mathrm{mg} / \mathrm{kg}$ or $400 \mathrm{mg} / \mathrm{kg}(0.4 \pm 0.03$ or $0.15 \pm 0.01, \mathrm{p}<0.05)$ when compared with non-treated mice $(0.5 \pm 0.02)$, respectively (Figure 1$)$.

\section{DISCUSSION AND CONCLUSION}

In this study, we demonstrated that intraperitoneal sub-acute treatment with AFL inhibited the anaphylactic shock reaction in OVA sensitized-BALB/c mice. The anaphylactic shock reaction may be lethal in atopic subjects and it is the most important symptom in hypersensitivity reaction type I (Finkelman et al., 2005; Strait et al., 2002). It has been described that plant extract used in folk Chinese medicine were capable to block shock responses and this effect was related with decreased IgE levels (Hyung-Min et al., 2001). Our study showed similar pattern, since the inhibition of the shock response in AFL treated mice was

Table 2. Serum levels of IgE in AFL treated and OVA-immunized mice

\begin{tabular}{lccc}
\hline & $\begin{array}{c}\text { Total serum IgE } \\
\text { Treatments }\end{array}$ & $\begin{array}{c}\text { OVA-specific IgE serum } \\
\text { titer }(\%)\end{array}$ & $\begin{array}{c}\text { OVA-specific Ig serum } \\
\text { titer }\end{array}$ \\
\hline OVA & $181(100)$ & $1: 1.373(100)$ & $1: 110.2$ \\
OVA + AFL $(\mathrm{mg} / \mathrm{kg})$ & & & - \\
200 & $22.5 \pm 6.1 *(12)$ & $1: 588^{*}(47)$ & - \\
400 & $35.2 \pm 4.3^{*}(19)$ & $1: 432 *(31)$ & -
\end{tabular}

${ }^{a}$ Groups of mice ( $\left.\mathrm{n}=10\right)$ were treated by intraperitoneal injection of the indicated doses of AFL (in $\left.\mathrm{mg} / \mathrm{Kg} / \mathrm{day}\right)$ and additionally sensitized with OVA. Control animal group (OVA) received saline during the OVA sensitization. After the treatment period, animals were bled and the sera of each group were pooled. Total serum IgE concentration was determined by capture ELISA. OVA-specific IgE titers were measured by ELISA. The last column shows the titers of OVA-specific antibody (determined by the PCA test). The basal concentration of total IgE $(5.10 \pm 1.27 \mu \mathrm{g} / \mathrm{ml}) \mathrm{was}$ obtained from animal that did not receive any treatment. Data are representative of three independent experiments. $* \mathrm{p}<0.001$ compared with control group (OVA).

(-): Undetectable 


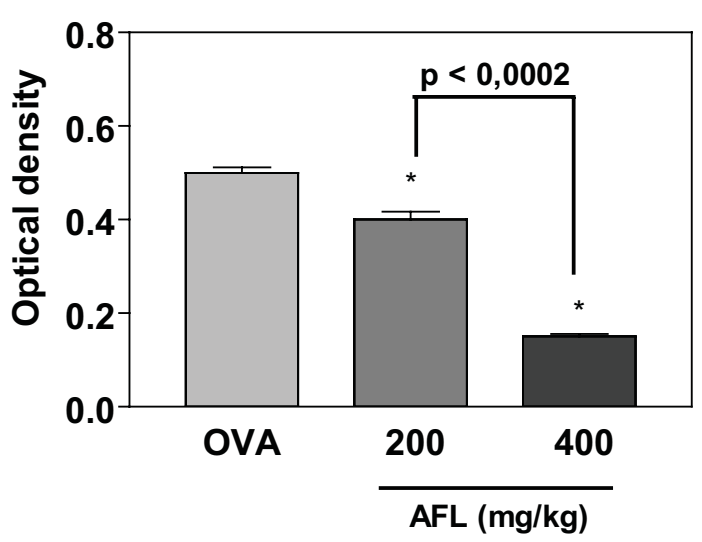

Figure 1. Effect of AFL on the background proliferative response. Groups of mice $(n=10)$ were treated by intraperitoneal injection of the indicated doses of AFL $(\mathrm{mg} / \mathrm{kg} /$ day) and additionally sensitized with OVA. Control animal group (OVA) received saline during the OVA sensitization. Spleen cells were obtained from each group of animals. Pooled spleen cells from each group were incubated at $5 \% \mathrm{CO}_{2}, 37^{\circ} \mathrm{C}$ for three days. The background cell proliferation was measured by the MTT test. Values are mean of optical density \pm standard error of the mean (SEM) of triplicate cell cultures.

$* p<0.001$ compared with control group (OVA).

related to lower total and OVA-specific serum IgE levels. Elevated IgE levels are associated with immediate-type allergic reactions (Mayr; Zuberi; Liu, 2003). Our data suggest that the intraperitoneal AFL administration may have an anti-allergic activity through the decrease of IgE production.

Th2 lymphocytes and its cytokines have a pivotal role in immediate allergic response (Packard; Khan, 2003). The inhibitory effect in the IgE production observed here could be for instance the result of an effect at the levels of cytokine production. Our previous results showed that spleen cells from normal BALB/c mice stimulated in vitro with AFL and Concanavalin-A produced high levels of IL-10 (Piuvezam et al., 1999). In addition, BezerraSantos (2004) demonstrated spleen cells from orally treated-AFL mice produced higher levels of both IFN- $\gamma$ and IL-10, when compared to control animals. The IL10 production in acute inflammatory diseases represents a favorable prognosis due to its anti-inflammatory effect (Jae-Won et al., 2002).

This prophylactic effect of the AFL could be related to an inhibitory effect on in vivo response to OVA. Indeed we observed that the AFL reduced the background proliferative cell response. This effect could be by an inhibition on basal cytokine production. It has been demonstrated that AFL reduced spleen cell proliferative response induced by Concanavalin-A and this effect was caused by increased of the IL-10 levels (Piuvezam et al., 1999).
AFL did not protect mice to anaphylactic shock reaction induced by compound $48 / 80$. It is well known that this compound is a potent mast cell degranulator (SeungHeon et al., 2005) and the mechanism involved in this anaphylactic response is not receptor dependent unlike IgE mediated response (Ferry et al., 2002). Besides that, it has been described that mast cell degranulators such as compound $48 / 80$ induce histamine release throughout a plasma membrane change (Kim et al., 2000). Our finds may suggest that AFL is acting directly in the IgE production.

The results presented here showed that intraperitoneal AFL treatment inhibited anaphylactic shock reaction, IgE production and cell proliferative response. These data highlight the important role of this plant in regulating the murine IgE production and suggest its regulatory role in cytokine production in an IgE-dependent hypersensitivity model.

\section{ACKNOWLEDGMENTS}

The authors are grateful to Dr. Magna Suzana Alexandre Moreira for ELISA experiments, Fernando Antônio Cavalcanti Viana for Cissampelos sympodialis collect and Jose Crispim Duarte for technical assistance. This work was supported by the CNPq and PRONEX.

\section{REFERENCES}

Alexandre-Moreira MS, Freire de Lima CG, Trindade MN, Castro-Faria-Neto HC, Piuvezam MR, Peçanha LMT 2003a. Cissampelos sympodialis Eichl. (Menispermaceae) leaf extract induces interleukin10-dependent inhibition of Trypanosoma cruzy killing by macrophages. Braz J Med Biol Res 36: 199-205.

Alexandre-Moreira MS, Piuvezam MR, Peçanha LMT $2003 \mathrm{~b}$. Modulation of B lymphocyte function by an aqueous fraction of the ethanol extract of Cissampelos sympodialis Eichl. (Menispermaceae). Bras J Med Biol Res 36: 1511-1522.

Barbosa-Filho JM, Agra MF, Thomas G 1997. Botanical, chemical and pharmacological investigation on Cissampelos species from Paraíba (Brazil). Ciência e Cultura - Journal of the Brazilian Association Advanced Science 49: 386-394.

Batista-Lima KV, Ribeiro RA, Balestieri FMP, Thomas G, Piuvezam MR 2001. Anti-inflammatory activity of Cissampelos sympodialis Eichl. (Menispermaceae) leaf extract. Acta Farm Bonaerense 20: 275-279.

Bezerra-Santos CR, Balestieri FMP, Rossi-Bergmann B, Peçanha LMT, Piuvezam MR 2004. Cissampelos sympodialis Eichl. (Menispermaceae): oral treatement decreases IgE levels and induces a Th1-skewed cytokine production in ovalbuminsensitized mice. J Ethnopharmacol 95: 191-197.

Cortes SF, Alencar JL, Thomas G, Barbosa-Filho JM 1995. Spasmolytic actions of warifteine, a bisbenzylisoquinoline alkaloid isolated from the root bark of Cissampelos sympodialis Eichl. 
(Menispermaceae). Phytother Res 9: 579-583.

Dai Y, Li-Fei H, Yiu-Pong C, Cheng L, Paul Pui-Hay B 2004. Inhibition of immediate allergic reactions by ethanol extract from Plumbago zeylanica Stems. Biol Pharm Bull 27: 429-432.

Ferry X, Brehin S, Kamel K, Landry Y 2002. G proteindependent activation of mast cell peptides and basic secretagogues. Peptides 23: 1507-1515.

Finkelman FD, Rothenberg ME, Brandt EB, Morris SM, Strait RT 2005. Molecular mechanisms of anaphylaxis: Lessons from studies with murine models. J Allergy Clin Immunol 115: 449-457.

Freitas MR, Cortes SF, Thomas G, Barbosa-Filho JM 1996. Modification of calcium metabolism in rabbit aorta as a mechanism of spasmolytic action of warifteine, a bisbenzylisoquinoline alkaloid isolated from the leaves of Cissampelos sympodialis Eichl. J Pharm Pharmacol 48: 335-338.

Grunewald SM, Werthmann A, Schmarr B, Klein CE, Bröcker EB, Mohrs M, Brombacher F, Sebald W, Duschl A 1998. An antagonistic IL-4 mutant prevents type I allergy in the mouse: Inhibition of the IL-4/IL13 receptor system completely abrogates humoral immune response to allergen and development of allergic symptoms in vivo. J Immunol 160: 40044009.

Holt PG, Rose AH, Batty JE, Turner KJ 1981. Induction of adjuvant-independent $\mathrm{IgE}$ responses in inbred mice: Primary, secundary and persistent IgE responses to ovalbumin and ovomucoid. Inter Arch Allergy Appl Immunol 65: 42-50.

Hyung-Min K, Joon-Ho L, Jin-Hee W, Eun-Jeung P, Han-Jung C, Hyung-Ryong K, Cheorl-Ho K, Seung-Hwa B 2001. Inhibitory effect on immunoglobulin E production in vivo and in vitro by Siegesbeckia glabrescens. Phytother Res 15: 572-576.

Jae-Won Oh, Seroogy CM, Meyer EH, Akbari O, Berry G, Fathman G, DeKruyff HR, Umetsu DT 2002. CD4 T-helper cells engineered to produce IL-10 prevent allergen-induced airway hyperreactivity and inflammation. J Allergy Clin Immunol 110: 460-468.

Kim SH, Choi YK, Jeong HJ, Kang HU, Moon G, Shin TY, Kim HM 2000. Suppression of immunoglobulin Emediated anaphylactic reaction by Alpynia oxyphylla in rats. Immunopharmacol Immunotoxicol 22: 267277.

Mayr SI, Zuberi RI, Liu FT 2003. Role of immunoglobulin E and mast cells in murine models of asthma. Braz J Med Biol Res 36: 821-827.

Moneret-Vautrin DA, Morisset M, Flabbee J, Beaudouin GK 2005. Epidemiology of life-threatening and lethal anaphylaxis: a review. Allergy 60: 443-451.

Mosmann T 1983. Rapid colorimetric assay for cellular growth and survival: application to proliferation and cytotoxic assays. J Immunol Methods 65: 55-63.

Oshiba A, Hamelmann E, Takeda K, Bradley KL, Loader JE, Larsen GL, Gelfand EW 1996. Passive transfer of immediate hypersensitivity and airway hyperresponsiveness by allergen-specific immunoglobulin (Ig) $\mathrm{E}$ and $\mathrm{IgG1}$ in mice. J Clin Invest 97: 1398-1408.

Packard KA, Khan MM 2003. Effects of histamine on Th1/Th2 balance. Inter Immunopharmacol 3: 909-920.

Phil-Dong M, In-Young C, Ho-Jeong N, Hyun-Ja J, Cheorl-Ho K, Hyung-Ryong K, Yun-Kyung K, Park SK, SeungHeon H, Hyung-Min K 2004. Rubus croceacanthus Leveille inhibits mast cell-mediated anaphylactic like reaction and tumor factor- $\alpha$ secretion. Biol Pharm Bull 27: 1359-1363.

Piuvezam MR, Peçanha LMT, Alexander J, Thomas G 1999. Cissampelos sympodialis Eichl. leaf extrac increases the production of IL-10 by concanavalina-A treated BALB/c spleen cells. J Ethnopharmacol 67: 93101.

Randolph DA, Carruthers CJL, Szabo SJ, Murphy KM, Chaplin DD 1999. Modulation of airway inflammation by passive transfer of allergen-specific Th1 and Th2 cells in a model of asthma. J Immunol 162: 23752383.

Scott HS, Donald YML 2004. Advances in allergic skin disease, anaphylaxis, and hypersensitivity reactions to foods, drugs, and insect stings. J Allergy Clin Immunol 114: 118-24.

Seung-Heon H, Jin-Mu Y, Hongjun K, Ho-Young C, Yun-Kyung K, Han-Jung C, Hyung-Ryong K, Cheorl-Ho Kim 2005. Inhibitory effects of Okbyungpoong-Gamhmi on anaphylactic responses. J Ethnopharmacol 98: 361-365.

Sherwin CM, Christiansen IJ, Duncan HWE, Lay Jr DC, Mench JA, O'Connor CE, Petherick JC 2003. Guidelines for the ethical use of animals in applied ethology studies. Appl Anim Behavr Sci 8: 291-305.

Snaper CM, Paul WE 1987. B cell stimulatory factor-1 (interleukin-4) prepares resting murine B cells to secrete $\operatorname{IgG1}$ upon subsequent stimulation with bacterial lipopolysaccharide. J Immunol 139: 1017.

Strait RT, Morris SC, Yang M, Xiao-Wu Qu, Finkelman 2002. Pathway of anaphylaxis in the mouse. J Allergy Immunol 109: 658-668.

Thomas G, Burnes F, Pyne S, Pyne NJ 1997. Characterization of the extract from the leaves of Cissampelos sympodialis Eichl. (Menispermaceae) on spontaneous tone of isolated trachea. Phytother Res 11: 496-499. 